\title{
TRADICINALNI MATERIJALI KAO REŠENJE ZA GRAĐENJE U NOVOM VREMENU KLIMATSKIH POREMEĆAJA
}

\author{
Milan Kekanović ${ }^{1}$ \\ Dragoslav Šumarac ${ }^{2}$ \\ Ljiljana Kozarić ${ }^{3}$ \\ Stanko Ćorić ${ }^{4}$ \\ Arpad $\check{C}^{5}$
}

UDK: 502.131.1:69

DOI: 10.14415/konferencijaGFS2019.053

Rezime: U radu su prezentovana iskustva autora rada i saznanja do kojih su došli analizirajući sopstvena merenja termo-dinamičkih karakteristika na tradicionalnim obnovljivim materijalima. Iskustva tradiocionalnog građenja i objekti koji postoje $u$ svetu, samo potvrđuju našu odlučnost da se maksimalno posvetimo razvoju novih sistema građenja uz primenu tradicionalnih materijala u izvornom ili delimično modifikovanom obliku. Naime, usled klimatskih promena već se dešavaju kratki letnji toplotni udari u Evropi i svetu. Veštački klima uređaji u takvim uslovima ne mogu biti rešenje za zaštitu ljudi u stambenim objektima. Jedino ispravno i moguće rešenje je da zidovi vršse klimatizaciju prostora i zaštitu ljudi na potpuno prirodan način u skladu sa termoduinamičkim fizikalnim zakonitostima razmene vodene pare a na taj način bi se vršilo i hlađenje zidova.

\section{Keywords:}

obnovljivi tradicionalni materijali, klimatske promene

\section{UVOD}

Ljudi su živeli i još uvek ugodno žive u kućama od nepečene gline, od drveta i kamena na svim kontinentima sveta. Postoji vrlo interesantan podatak, da danas u svetu više od 3 milijarde ljudi živi u kućama od nepečene gline.

\footnotetext{
${ }^{1}$ Milan Kekanović, Associate Professor Ph.D. ,Faculty of Civil Engineering Subotica, University of Novi Sad, Kozaračka 2a, 24000 Subotica, Serbia,E-mail: kekec@gf.uns.ac.rs

${ }^{2}$ Dragoslav Šumarac, Professor Ph.D. Faculty of Civil Engineering in Belgrad, Bulevar Kralja Aleksandra 73, 11000 Beograd, Serbia, E-mail: sumi@eunet.rs

${ }^{3}$ Ljiljanja Kozarić,Assistant Professor Ph.D. Faculty of Civil Engineering Subotica, University of Novi Sad, Kozaračka2a, 24000 Subotica,Serbia,E-mail:kozaric@gf.uns.ac.rs

${ }^{4}$ Stanko Ćorić,Assistant Professor Ph.D. Faculty of Civil Engineering in Belgrad, Bulevar Kralja Aleksandra 73, 11000 Beograd, Serbia E-mail: cstanko@grf.bg.ac.rs

${ }^{5}$ Arpad Čeh, Assistant. ,Faculty of Civil Engineering Subotica, University of Novi Sad, Kozaračka 2a, 24000 Subotica, Serbia, E-mail: ceh@gf.uns.ac.rs
} 


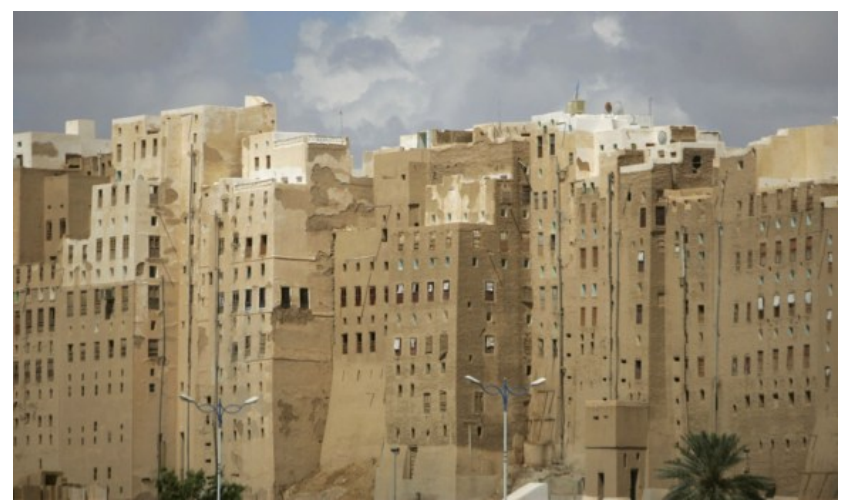

Slikal. Stari soliteri od zemlje izgrađeni pre više vekova - grad Shibam u Jemenu

Najviše takvih gradnji ima u Africi, Aziji, Južnoj i Srednjoj Americi. Možda bi neko pomislio da se tamo nalaze siromašne zemlje i siromašni narodi. Siromaštvo nije razlog za takvu gradnju već klimatsko podneblje sa visokim temperaturama i visokom relativnom vlažnošću. U takvim podnebljima postoje samo dve alternative za život ljudi u stambenim objektima:

izuzetno skupa veštačka klimatizacija koja troši veliku količinu električne energije prirodna klimatizacija preko zidova stambenih objekata

Klimatizacija preko zidova stambenih objekata je korišena i dokazana kroz više vekova. Ovaj način klimatizacije pruža najbolji ugođaj za čoveka. Niti jedan drugi način, veštačka klima ili slično, ne može da obezbedi takav ugođaj kao prirodna klimatizacija preko zidova i tavanica. Prvi uslov koji moramo ispoštovati za prirodnu klimatizaciju je da zidove objekata napravimo sa takvim materijalima koji su higroskopni i parodifuzni. Drugi uslov je da na takve zidove ne smemo postaviti nikakve materijale koji bi tu parodifuznost sprečili ili otežali. To znači da moramo voditi računa da čak i farbe na zidovima moraju biti paropropusne. Primeri gradnje sa nepečenom glinom i drugim prirodnim materijalima postoje i u Evropi, pa tako i u R.Srbiji.

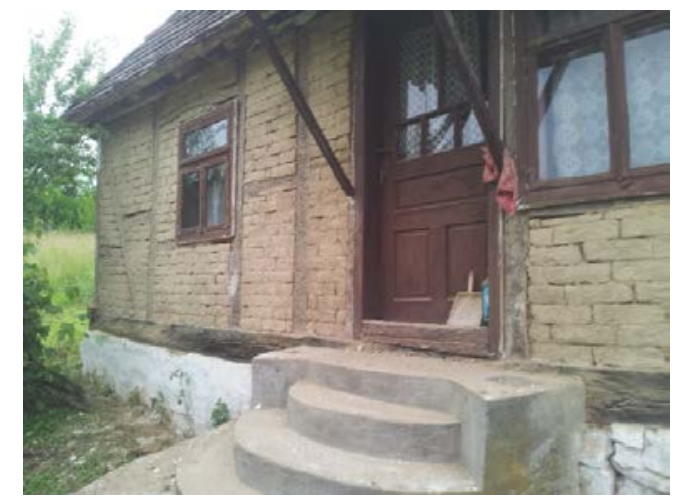

Slika 2. Kuća građena u Bondruk sistemu sa kombinacijom drvenog skeleta i čerpića od nepečene gline 


\section{$7^{\text {th }}$}

INTERNATIONAL CONFERENCE

Contemporary achievements in civil engineering 23-24. April 2019. Subotica, SERBIA

Tako se gradilo nekada a gradi se i danas, sve više u Evropi, gde bogati ljudi, sa dobrim finansijama grade svoje stambene objekte od nepečene gline u obliku naboja ili zidane objekte sa elementima od nepečene gline, popularnim čerpićem.

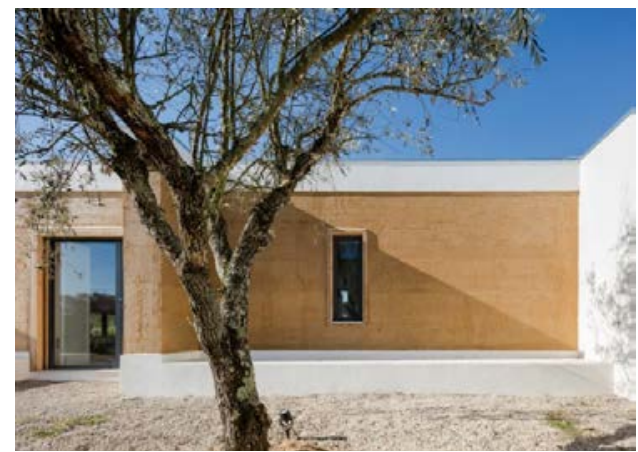

Slika 3. Primer gradnje novog objekta sa nepečenom glinom u Portugalu

\section{PRIRODNI MATERIJALI ZA GRAĐENJE U NOVOM VREMENU - PREDNOSTI I NEDOSTACI}

U ovome radu, pored mnogih prirodnih materijala, mi obrađujemo samo pojedine, koji se i danas najviše primenjuju a to je drvo, kamen, nepečena glina, trska i slama.

\subsection{Drvo kao građevinski materijal}

Drvo je materijal koji ima dobre termoizolacione karakteristike, što je danas vrlo bitno, zbog trenda podizanja energetske efikasnosti kod građevinskih objekata. Mehaničke karakteristike drveta su na zavidnom nivou u odnosu na druge materijale i one zavise od stanja vlažnosti samog drveta. Nedostatci drveta kao građevinskog materijala su relativno visoka cena i stalna potreba za zaštitom drveta od insekata i fungi (gljiva). Najveći nedostatak drveta je slaba protivpožarna otpornost. Primena drveta kod građenja stambenih objekata nikada nije prestajala i pored navedenoh nedostataka, drvo je jedan od materijala za koje je čovek najviše vezan.

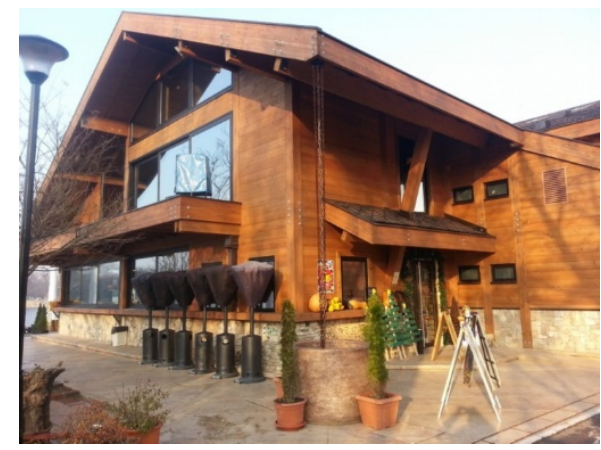

Slika 4. Objekat građen sa drvenim elementima zidova i krovova koji već svojim spoljašnjim izgledom pleni svojom lepotom i toplotom - Sunset caffe Beograd 
Савремена достигнућа у грађевинарству 23-24. април 2019. Суботица, СРБИЈА

Zidovi kuća od drveta ipak trebaju imati dodatnu termo izolaciju, ako želimo i moramo zodovoljiti propise građenja energetski efikasnih objekata. Drvo je istovremeno i dekoritivno i završno, kako na spoljašnjoj strani tako i na unutrašnjoj strani. Termodinamički proračun za translatorni gubitak toplote kod zidova od drveta, prema jednačini (1) bi upućivao da debljina takvih zidova treba biti najmanje $45 \mathrm{~cm}$, pod uslovom da nemamo dodatnu termoizolaciju sa klasičnim termo izolacionim materijalima.

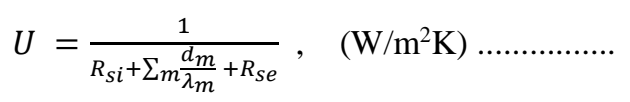

$R_{s i}, R_{s e}$ - otpor prelazu toplote sa vazduha na zid (strop, pod) i sa zida (tavana) na vazduh $\left(\mathrm{m}^{2} \mathrm{~K} / \mathrm{W}\right)$

$d_{m}$ - debljina m-tog sloja materijala

$\lambda_{m}$ - toplotna provodljivost $\mathrm{m}$-tog sloja materijala (W/mK)

Ako uvrstimo vrednosti toplotne provodljivosti za drvo koje ima vrednost, prema Pravilniku za energetsku efikasnost zgrada R.Srbije, $\lambda=0,14 \mathrm{~W} / \mathrm{mK}$, tada za debljinu takvog zida od drveta od $\mathrm{d}=45 \mathrm{~cm}$ dobijamo da je vrednost prelaza toplote $\mathrm{U}=0,29$ $\mathrm{W} / \mathrm{m}^{2} \mathrm{~K}$, prema jednačini (2).

$$
U=\frac{1}{0,125+\frac{0,45}{0.14}+0,04}=0,29 \mathrm{~W} / \mathrm{m}^{2} \mathrm{~K}<0,3 \mathrm{~W} / \mathrm{m}^{2} \mathrm{~K}
$$

Vidimo da se radi o suviše velikoj potrebnoj debljini zidova od drveta, da bi oni zadovoljili propis prelaza toplote koji se zahteva prema Pravilniku za energetsku efikasnost zgrada R.Srbije. Ovi propisi su u zemljama EU i mnogo stroži, što upućuje na potrebu još veće debljine drvenih zidova. Ovakvi rezultati upućuju da drvo kao materijal baš i nema zadovoljavajuće termo izolacione karakteristike jer su potrebne velike debljine zidova što može da odvrati investitore da primenjuju drvene kuće. Praktična iskustva su potpuno drugačija jer merenja potrošnje toplotne energije kod drvenih kuća sa zidovima debljine $25 \mathrm{~cm}$, što je za $44 \%$ manje od izračunate vrednosti, upućuje na zaključak da je ta potrošnja u granicama C klase (razreda) koju propisuje Pravilnik za energetsku efikasnost zgrada R.Srbije, kao krajnju dozvoljenu. Fizikalno objašnjenje za takve praktične rezultate nije jednostavno i nije predmet ovoga naučnog rada.

\subsection{Kamen kao građevinski materijal}

Kuće od kamena deluju hladno i vrlo su otporne i trajne, za razliku od drvenih kuća. Zidovi od kamena ni proračunski a ni praktično ne zadovoljavaju zahtevane uslove po pitanju energetske efikasnosti. Na zidove od kamena se mora staviti termo izolacija, kako bi takvi zidovi zadovoljili zahtev po pitanju dozvoljenog prelaza toplote U $\left(\mathrm{W} / \mathrm{m}^{2} \mathrm{~K}\right)$. Ako se kamen nalazi na fasadi, kao dekorativni i zaštitni element, onda se termo izolacija mora postaviti na unutrašnju stranu. Termo izolacija na unutrašnjoj strani zidova može biti dobro rešenje, naročito u podnebljima sa Mediteranskom klimom. 
Contemporary achievements in civil engineering 23-24. April 2019. Subotica, SERBIA

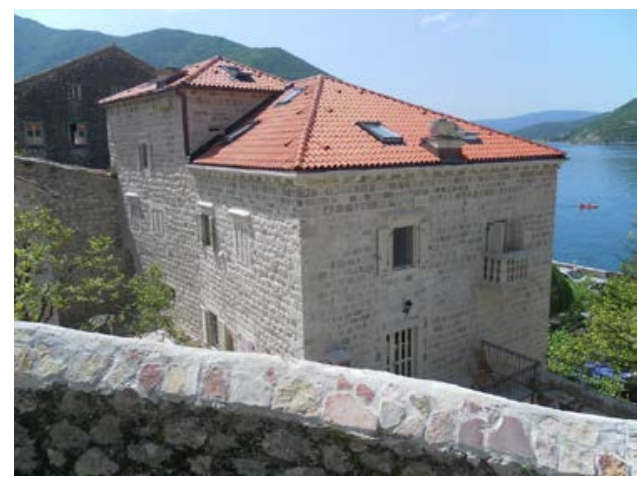

Slika 5. Kuća od kamena u Perastu (Crna Gora) stara 400 godina, pod zaštitom UNESCO, sanirana je po pitanjima nosivosti i sigurnosti i zadovoljava visoke standarde energetske efikasnosti

\subsection{Nepečena glina kao građevinski materijal u obliku čerpića i naboja}

Zidovi i kuće od nepečene gline pored mnogih prednosti koje su ovaj materijal i način gradnje zadržali do danas, postoje i nedostatci. Osnovni nedostatak je slaba otpornost na delovanje vode i povećanja vlažnosti zidova. Voda i visoka vlažnost raskvašavaju nepečenu glinu što može da ugrozi stabilnost celog objekta. Ovaj nedostatak se praktično otklanja na način da se takvi objekti ne trebaju i ne smeju graditi u poplavnim područijima. Navedeni nedostatatak ne sme i ne može predstavljati razlog da se nepečena glina kao materijal i način gradnje zabrani ili na bilo koji drugi način ograničava jer su prednosti daleko iznad nedostataka. Na žalost može se steći utisak da se ovaj materijal u R.Srbiji ne smatra dovoljno dobrim za gradnju.

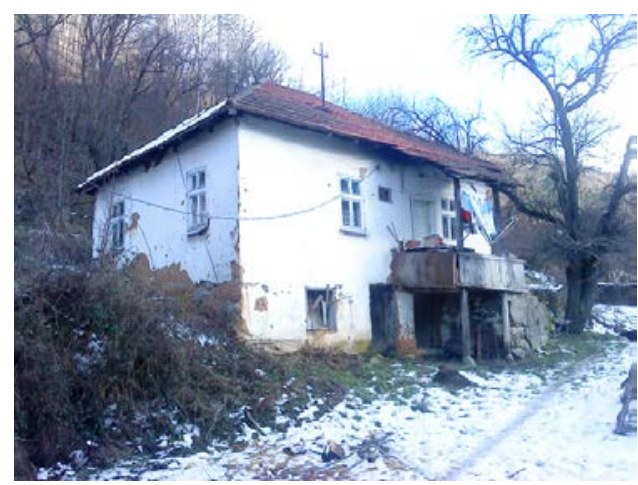

Slika 6. Kuća na Staroj planini koja je i sama stara više vekova a građena je sa nabojem od nepečene gline

U Pravilniku za energetsku efikasnost zgrada R.Srbije u tabeli termotehničkih karakteristika ne postoje vrednosti za nepečenu osušenu glinu čerpića ili naboja, za toplotnu provodljivost $\lambda(\mathrm{W} / \mathrm{mK})$ za prelaz toplote $\mathrm{U}(\mathrm{W} / \mathrm{m} 2 \mathrm{~K})$, specifične toplote $\mathrm{c}$ $(\mathrm{J} / \mathrm{kgK})$ i za faktor otpora difuziji vodene pare $(\mu)$. Ova činjenica može značiti da je to 
Савремена достигнућа у грађевинарству 23-24. април 2019. Суботица, СРБИЈА

ispušteno slučajno a isto tako, može značiti da je ovaj materijal degradiran kao nekvalitetan i nepoželjan. Ovo zadnje nikako ne bi smelo da se tumači, jer su zidovi od gline najbolji prirodni regulatori mikro klime u prostorijama zahvaljujući njenoj higroskopnosti. Naime, glina je više higroskopna i od drveta. Zahvaljujući takvoj higroskopnosti, zid od nepečene gline uzima vodenu paru iz vazduha u prostoriji i ta vodena para odlazi na spoljašnju stranu zida, što će fizikalno biti objašnjeno u narednom poglavlju. Obzirom da navedene vrednosti nisu date u Pravilniku za energetsku efikasnost zgrada R.Srbije, autori ovoga rada su izmerili vrednost toplotne provodljivosti $\lambda(\mathrm{W} / \mathrm{mK})$ kod nepečene osušene gline, popularnog čerpića, pomoću instrumenta Isomet 2114 i ovom prilokom ih iznosimo pred stručnu i naučnu javnost:

- Zapreminska masa čerpića $\gamma=1190 \mathrm{~kg} / \mathrm{m}^{3}$

- Toplotna provodljivost čerpića pri vlažnosti $H_{a}=4,3 \%, \lambda=0,24 \mathrm{~W} / \mathrm{mK}$

Izmerena vrednost toplotne provodljivosti kod čerpića upućuje na zaključak da je ovaj materijal vrlo dobar termoizolator. Ova vrednost može biti i nešto niža i na tome radimo kao autori ovoga rada, zajedno sa našima studentima u okviru nastavnih predmeta, na Građevinskom fakultetu Subotica - Univerziteta u Novom Sadu i na Građevinskom fakultetu Beograd - Univerziteta Beograd.

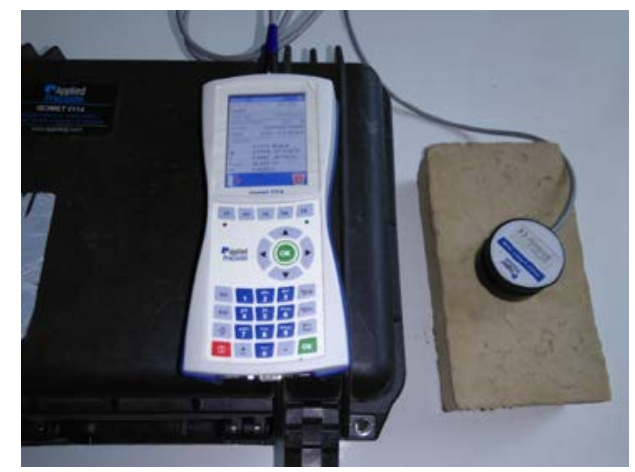

Slika 7. Merenje toplotne provodljivosti kod čerpića kao elementa od nepečene gline koji su napravili studenti Građevinskog fakulteta u Subotici

\subsection{Slama i trska kao građevinski materijali}

Slama i trska se kao materijali najmanje primenjuju kod građenja kuća u R.Srbiji i Evropi. Razlozi su objektivni i subjektivni. Objektivni razlozi su da trska i slama jesu podložni propadanju u toku vremena ako bi bili izloženi vlazi. Isto tako, ovi materijali su osetljivi na požar. Subjektivni razlozi su rezultat istorijskog graditeljskog nasleđa gde se u Evropi i R. Srbiji najčešće grade kuće, „tvrđave“, sa materijalima koji imaju visoke mehaničke karakteristike, koji su masivni, kao što je beton i elementi od pečene gline. Novi trendovi u Evropi i svetu, kada se sve više zabranjuje eksploatacija peska i šljunka iz reka, građenje građevinskih objekata će morati biti usmereno prema ovim obnovljivim materijalima kao što su slama i trska. Postoji još jedan razlog a to je energetska efikasnost građevinskih objekata koja se postavlja kao uslov građenja. Slama i trska 
Contemporary achievements in civil engineering 23-24. April 2019. Subotica, SERBIA

imaju veliku prednost pred mnogim drugim materijalima po tom pitanju jer imaju mnogo bolje termotehničke karakteristike.

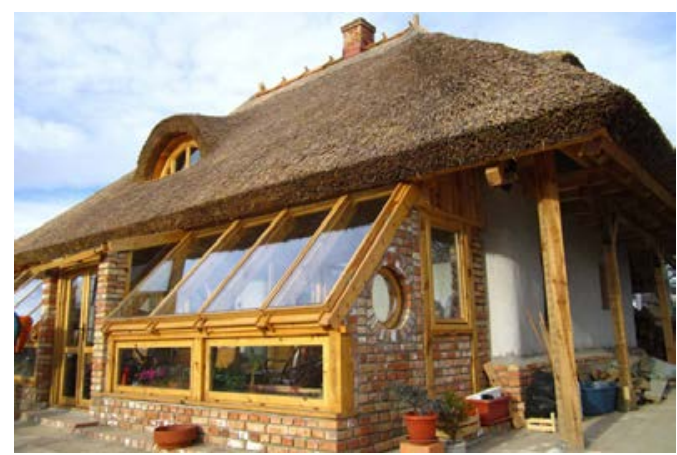

Slika 8. Prelepa kuća visoke energetske efikasnosti gde su zidovi urađeni sa slamom a krov je prekriven trskom

U tom smislu smo kao autori želeli dati svoj doprinos, te smo izvršili sopstvena merenja termotehničkih karakteristika ovih materijala, slame i trske, jer su nam vrednosti date $\mathrm{u}$ Pravilniku za energetsku efikasnost zgrada bile malo nelogične.

Tabela 1.: Skenirana tabela termotehničkih vrednosti za trsku i slamu iz Pravilnika za energetsku efikasnost zgrada R.Srbije

\begin{tabular}{|c|c|c|c|}
\hline Материјал / производ & $\begin{array}{l}\text { Густина, } \\
\rho \\
\mathrm{kg} / \mathrm{m} 3\end{array}$ & $\begin{array}{l}\text { Специфична } \\
\text { топлота, } \\
\text { с } \\
\mathrm{J} /(\mathrm{kg} \times \mathrm{K}) \\
\end{array}$ & \begin{tabular}{|l|} 
Топлотна \\
проводљивост, \\
$\lambda$ \\
$\mathrm{W} /(\mathrm{m} \times \mathrm{K})$ \\
\end{tabular} \\
\hline \multirow{2}{*}{ 98. Плута, експандирана, импрегнирана } & 120 & 1670 & 0,041 \\
\hline & 160 & 1670 & 0,044 \\
\hline 99. Плоче од прошивене трстике & 800 & 1260 & 0,046 \\
\hline 100. Плоче од пресоване сламе (страмит) & 350 & 1470 & 0,098 \\
\hline
\end{tabular}

U Tabeli 1 . je data vrednost toplotne provodljivosti $\lambda=0,098 \mathrm{~W} / \mathrm{mK}$ za presovanu slamu koja je ograničeno prisutna na tržištu. Autori ovoga rada za stručnu i naučnu javnost su izmerili vrednost toplotne provodljivosti za baliranu slamu na instrumentu Isomet $2114 \mathrm{i}$ sa zadovoljstvom prikazujemo tu izmerenu vrednost koja je neuporedivo manja od vrednosti za presovanu slamu. 


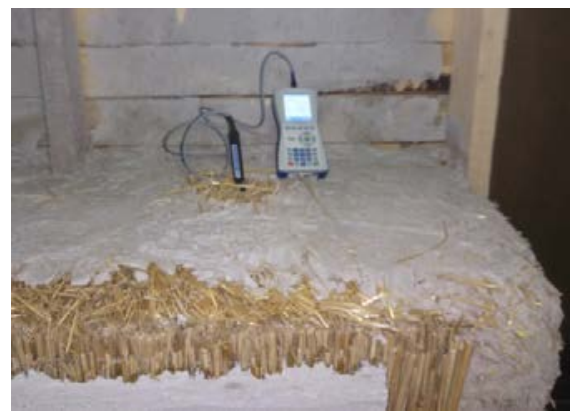

Slika 9. Merenje toplotne proviodljivosti $\lambda$ (W/mK) pomoću instrumenta Isomet $2014 \mathrm{sa}$ iglastom sondom u modelu zida sa baliranom slamom koji su uradili studenti Građevinskog fakulteta iz Subotice

- Zapreminska masa balirane slame $\gamma=110 \mathrm{~kg} / \mathrm{m}^{3}$

- $\quad$ Toplotna provodljivost balirane slame pri vlažnosti $H_{a}=1,6 \%, \lambda=0,06 \mathrm{~W} / \mathrm{mK}$

U istoj Tabeli 1. je data vrednost toplotne provodljivosti za prošivenu trsku koja iznosi $\lambda$ $=0,046 \mathrm{~W} / \mathrm{mK}$, kod zapreminske mase koja je napisana da ima vrednost $800 \mathrm{~kg} / \mathrm{m}^{3}$. Autori ovoga rada su izmerili trščanu ploču debljine $10 \mathrm{~cm}$ i utvrdili da zapreminska masa iznosi $130 \mathrm{~kg} / \mathrm{m}^{3}$ a toplotna provodljivost $\lambda=0,07 \mathrm{~W} / \mathrm{mK}$.

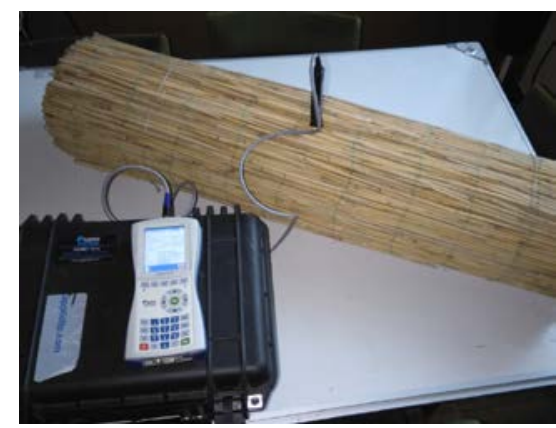

Slik1 10. Merenje toplotne proviodljivosti $\lambda$ (W/mK) kod trske u laboratoriji

Građevinskog fakulteta u Subotici pomoću instrumenta Isomet 2014 sa iglastom sondom

- Zapreminska masa trščane ploče $\gamma=130 \mathrm{~kg} / \mathrm{m}^{3}$

- Toplotna provodljivost urolovane prošivene trske pri vlažnosti $H_{a}=2,5 \%, \lambda=$ 0,07 W/mK

Vrednosti toplotne provodljivosti, kod trske, kako su date u Pravilniku za energetsku efikasnost zgrada R.Srbije nisu relevantne niti kada je u pitanju zapreminska masa niti kada je u pitanju toplotna provodljivost. Poseban problem je što podatak za toplotnu provodljivost kod trske prema Pravilniku za energetsku efikasnost zgrada R.Srbije može dovesti do velike greške pri proračunu toplotnih gubitaka u obliku prelaza toplote $U$ $\left(\mathrm{W} / \mathrm{m}^{2} K\right)$ prema jednačini (1). Uzimamo za primer slučaj da je projektovana termoizolacija na zgradi koja je od trske i ako bi projektant koristio podatak za toplotnu 
Contemporary achievements in civil engineering 23-24. April 2019. Subotica, SERBIA

provodljivost iz Pravilnika za energetsku efikasnost zgrada R.Srbije koji je tamo dat kao $\lambda=0,046 \mathrm{~W} / \mathrm{mK}$ a ta vrednost stvarno iznosi $\lambda=0,07 \mathrm{~W} / \mathrm{mK}$, tada bi se praktično pojavili veći gubitci toplotne energije na spoljnjim fasadnim zidovima za $34 \%$. Površina fasadnih spoljnjih zidova je najveća, što znači da su tamo i gubitci najznačajniji. Sve ovo upućuje da bi kod takvog proračuna, pogrešili najmanje za jedan razred (jednu klasu). Drugim rečima, ako bi proračunom dobili da je kod takvog objekta, izolovanog sa trskom kao termoizolacijom, zadovoljena C klasa, praktično bi to značilo da smo pogrešili u proračunu jer bi gubitci energije bili za 34\%. To znači da bi pogrešno vrednovali klasu zgrade i umesto C klase dobili bismo D klasu. Smatramo da nije potrebno da ističemo kakve bi to negativne posledice izazvalo po investitore i kupce nekretnina u takvoj zgradi.

\section{FIZIKALNO OBJAŠNJENJE KLIMATIZACIJE PROSTORIJA ZGRADA PREKO ZIDOVA}

U uvodnom delu ovoga rada smo već naglasili razloge da u podnebljima sa tropskom klimom gde su vrlo visoke temperature koje idu čak i do $+50^{\circ} \mathrm{C}$ a relativna spoljašnja vlažnost može biti preko $90 \%$, najbolje rešenje za klimatizaciju prostorija zgrada predstavljaju debeli zidovi od nepečene gline. Debeli zidovi od nepečene gline su u stanju uspešno izvršiti klimatizaciju prostorija jer je spoljašnja strana zidova zagrejana i isušena, kako je to prikazano na Slici 11 [1]. Na spoljašnjoj strani zida vlažnost $\mathrm{H}_{1}$ je najmanja i ona teži vrednosti $\mathrm{H}_{1}=\mathrm{H}=0 \%$. Vlažnost zida $\mathrm{H}_{5}$ na unutrašnjoj strani zida je najveća jer je glina higroskopan materijal koji upija vlagu iz vazduha u prostoriji. Na taj način se u prostoriji snižava relativna vlažnost vazduha $\varphi_{i}$ (\%) samim tim i temperatura vazduha se spušta jer imamo manjak vodene pare u vazduhu a na taj način i manje toplote koja je vezana na vodu zbog specifične toplote $c(\mathrm{~J} / \mathrm{kgK})$. Na unutrašnjoj strani zida imamo pritisak vodene pare $P_{i 1}=\varphi_{i 1} \cdot P_{i 1}(\mathrm{kPa})$ a na spoljašnjoj strani taj pritisak teži vrednosti $P_{e 2}=\varphi_{e 2} \cdot P_{e 2}^{\prime}=0(\mathrm{kPa})$ jer je zid suv. Na spoljašnjoj strani nema vodene pare jer vlažnost teži vrednosti $\mathrm{H}_{1}=\mathrm{H}=0 \%$. To automatski znači da je i relativna vlažnost na spoljašnjoj strani zida $\varphi_{e 2}=0 \%$.

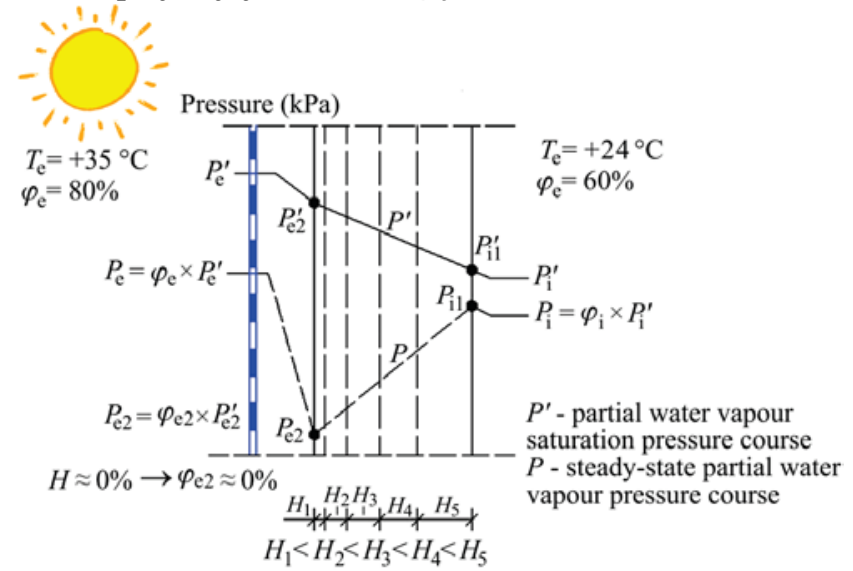

Slika 11. Fizikalno objašnjenje razmene vodene pare između unutrašnjeg i spoljašnjeg prostora- prirodan efekat hlađenja prostorija i zidova [1] 
Prema zakonu fizike pritisak vodene se kreću uvek sa mesta višeg pritiska prema mestu nižeg pritiska. To znači da će se vodena para kretati sa unutrašnje strane zida prema spoljašnjoj strani zida. U prostorijama zgrade će biti snižena vlažnost a na taj način i količina toplote odnosno biti će niža temperatura vazduha, što naročito pogoduje dobrom ugođaju za ljude koji borave u takvim prostorima. Postoji još jedan detalj i naročito interesantan fizikalan proces. Toplota sa spoljnje strane zida se kreće prema unutrašnjoj strani zida. Vodena para, kao što smo već naglasili, se kreće prema spoljašnjoj strani zida i ona vezuje na sebe toplotu jer ima veliki toplotni kapacitet. Na taj način, vodena para hladi zid jer sa sobom prema spoljnjoj strani iznosi i toplotu iz zida. Ovo je potpuno prirodan fizikalni proces i mi ga samo moramo omogućiti na način da ne zatvaramo zidove hrermetički, kako to tumače neki koji zagovaraju veštačku ventilaciju. Na žalost i Pravilniku za energetsku efikasnost zgrada R.Srbije tumači i računa da na spoljnjim zidovima postoje ventilacioni gubitci. Takvo tumačenje upućuje projektanta da spreči taj ventilacioni gubitak hermetičkim zatvaranjem zidova što je u potpunoj suprotnosti sa ovim tumačenjima prirodnog načina klimatizacije prostorija zgrade koji iznosimo u ovome radu. Ventilacioni gubitak je pojam koji se vezuje za prozore i za vrata a ne za zidove. Autori ovoga rada, stoga upućuju da se Pravilnik za energetsku efikasnost zgrada R.Srbije koriguje u smislu da ne upućuje na hermetičko zatvaranje zidova zgrada. Isto tako, potrebno je da se kod primene materijala i termoizolacija na zidovima uvek koriste mereni rezultati iz atesta materijala a nikako rezultati koji su dati u tabelama.

\section{ZAKLJUČCI}

Autori u ovome radu analiziraju i upućuju stručnu i naučnu javnost u mogućnosti primene tradicionalnih materijala sa dokazanim prednostima kroz više vekova. Tu se pre svega misli na mogućnost potpuno prirodnog načina klimatizacije prostorija zgrada preko zidova. Potrebno je da se u zidovima primene materijali koji su higroskopni i da se takvi zidovi ne zatvaraju bilo kakvim premazima koji bi otežali difuziju vodene pare. $\mathrm{Na}$ žalost, u ovom novom vremenu pomalo je struka zaboravila i zanemarila ove prirodne fizikalne procese, koje smo kao autori objasnili u ovome naučnom radu. U slučaju nailaska letnjih toplotnih udara zbog klimatskih poremećaja, ljudi će imati najbolju šansu za opstanak upravo u takvim objektima koji bi bili u stanju da preko zidova na prirodan način vrše klimatizaciju. Zidovi mogu biti i danas građeni sa ovim tradicionalnim materijalima u izvornom ili modifikovanom smislu, prilagođenom novim trendovima građenja.

\section{LITERATURA}

[1] Kekanović M., Aladžić V., Čeh A.: THE VAULTS OF THE SUBOTICA SYNAGOGUE AFTER 114 YEARS: CONDITION ASSESSMENT AND REPAIR RECOMMENDATIONS, Tehnicki vjesnik - Technical Gazette, 2018, Vol. 25, No 1, pp. 188-194, ISSN 1330-3651, UDK: https://doi.org/10.17559/TV-20161228143712

[2] Kozarić Lj., Kukaras D., Prokić A., Bešević M., Kekanović M.: Slip modulus of screws in timber and lightweight concrete composite structures, BioResources, 2018, Vol. 13, No 3, pp. 6021-6032, ISSN 1930-2126 
Contemporary achievements in civil engineering 23-24. April 2019. Subotica, SERBIA

[3] Kekanović M., Šumarac D., Kasaš K., Čeh A.: TOPLOTNA PROVODLJIVOST SUVOG I VLAŽNOG MATERIJALA ZIDOVA - VAŽAN UTICAJ NA ENERGETSKU EFIKASNOST OBJEKATA, 4. Savremena dostignuća u građevinarstvu, Subotica: Građevinski fakultet Subotica, 22 April, 2016, pp. 425-430, ISBN 978-86-80297-63-7, UDK: 536.2.022

[4] Kekanović M., Šumarac D., Ćorić S., Kasaš K., Čeh A., RENEWABLE BUILDING MATERIALS FOR HIGH ENERGY EFFICIENCY CONSTRUCTION ERA, 5th Intenational Conference CONTEMPORARY ACHIEVEMENTS IN CIVIL ENGINEERING, Faculty Of Civil Engineering Subotica, pp. 313 - 323, DOI: 10.14415/konferencija GFS2018.031, UDK: 691:502.131.1 Subotica, 20. April, 2018.

\title{
TRADITIONAL MATERIALS AS A SOLUTION TO CONSTRUCTION IN THE NEW AGE OF CLIMATE DISTURBANCES
}

\begin{abstract}
The paper contains authors' experiences and findings that were yielded as a result of measurements of thermodynamic properties of traditional renewable materials. As a testament to the quality of existing traditional constructions and construction techniques that are already scattered around the world, we have only grown stronger in our decision to completely dedicate ourselves to the development of new construction systems with the application of traditional materials in their original or partially altered form. To digress a little, climate changes already result in short summer heat waves in Europe and the world. Artificial air conditioners are not a proper solution for the protection of the people in housing objects. The only correct and plausible solution is for the walls to provide air-conditioning of the inner space and also the protection of the people which would be done in a completely natural way in accordance to the thermodynamic laws of water vapour exchange which in turn would provide cooling of the walls.
\end{abstract}

Keywords: renewable traditional materials, climate changes 